experience to examine such techniques and concepts as brain-storming, organization structure, decision-making, and the essentials of leadership to show how jejune even the most sophisticated managements can be in their enthusiastic adulation of the latest device for solving all problems; Uris shows only too clearly that management by craze is no substitute for management using intelligence, experience and application.

The third section will be useful to those specifically charged with developing managers in industry and commerce and here, too, the author shows that there are no short cuts to success. With detailed appraisals of management oducation and training schemes in small and large companies, as well as leading Amorican universities, this section would help many British readers to get a bird's-eye view of what is happening in the United States. This also applies to the last quarter of the book and, although Uris makes too much of the contribution of his own organization in providing education for management, his account of the work of the American Management Association will be received gratefully by specialist and generalist alike. Established forty years ago, and now with an annual income of $£ 2 \frac{1}{2}$ million, the work of the American Managemont Association in promoting productivity in Amorican industry, agriculture and commerce has been unrivalled. All managers and administrators should read this chapter at least and should then go on to help build up the British Institute of Management as a voluntary organization of comparable size and influence. The effects on British industry would be inestimable.

T. H. HAWKINS

\section{SCIENCE OF LEADERSHIP}

\section{Leadership and Organization}

A Behavioral Science Approach. By Robert Tannenbaum, Irving R. Weschler and Fred Massarik. (McGraw-Hill Series in Management.) Pp. xiv +456. (New York: MeGraw-Hill Book Company, Inc.; London: MeGrawHill Publishing Company, Ltd., 1961.) $58 s$.

T HIS book comprises a selection of writings during the decade 1950-60 of members of the Human Relations Research Group, Institute of Industrial Relations and Graduate School of Business Administration, University of California. They are arranged in three soctions. The first deals with leadership and what is described as the 'influence process'. It outlines some basic issues in human relations and analyses what is implied in leadership and attempts to influence others. The second discusses 'sensitivity training', by which is understood the development of skill and understanding in human relations and their handling. In the third part are presented what are described as 'studies in organization', which include, besides the concept of management and the nature of the process of taking decisions, decidedly sketchy analyses of the organization of research and the evaluation of the effectiveness of research which virtually ignore any of the substantial contributions to the slender literature in this field. Finally, almost four hundred pages on these themes are followed by throe independent critical commentaries, one by G. R. Bach, one by R. Dubin and one by L. F. Urwick. Withal there is a bibliography of publications of the Human Relations Research Group and a select annotated bibliography of other works.

The titles of the threo parts give at least a hint of the besetting weakness of the book, for which, moreover, its sub-title, "A Behavioral Science Approach", may also prepare the reader. Nor is it jargon alone that makes the book heavy going: it is excessively verbose, and for all the value and importance of the themes discussed and of some of the suggestions made, its verbiage may well deny it precisely the readers who conld most benefit from the attempted exposition. From the communication point of view it is far less effective than it might have been had sounder judgment been exercised in selecting material for inclusion, let alone in the writing.

One is led, in fact, to wonder just what this particular approach has contributed to justify all this time and effort. What exactly is to be found that Leighton has not expressed far more lucidly and cogently in The Gov. erning of Men, that is not to be found in the Lectures on Leadership of the Walker Trust or in Field-Marshal Sir William Slim's address Leadership ? The last, at least, is quoted by Urwick in his commentary, which is itself by far the best thing in the book and in its references introduce the reader to literature of a quality for the most part far above the level of that elsewhere cited. There, at least, are to be found names like those of Fayol, Mayo, Barnard, Follett, Rothlisberger, Mooney and Reilly, which demonstrate, as Urwick himself does, that it is possible to deal effectively with such themes as management and human relations in pellucid English unmarred by jargon. From the point of view of effective communication alone, the book warrants the suggestion that the would-be expositor of such themes should first imbibe Quiller-Couch's lecture on jargon. In support of this suggestion, a comparison of what is writton here on the introduction of change with the study Technical Change of Industrial Relations by Dr. W. H. Scott and his research team at the University of Liverpool provides sufficient evidence when due allowance has been made for the difference in scale and thoroughness of treatment. As it stands, it is all too probable that the book will fail to stimulate the self-examination and critical thinking on human relationships and the development of ability in management which the immense amount of work that has gono to its making was intended to provoke. R. BRIGHTMAN

\section{FREE SCHOOL CAVENDISH}

The Cavendish Laboratory

Nursery of Genius. By Egon Larsen. Pp. $95+23$ plates. (London: Edmund Ward (Publishers), Ltd., 1962.) 15s. net.

$\mathbf{T}$ is difficult to write temperately about this book. The claim on the dust jacket is already intemperate: "Here, for the first time, is its whole story, telling of the fundamental sciontific ideas and discoveries which originated there ...". Within the stiff covers of the book the "whole story" occupies 83 pages of genorous print, fragmented into twolve short chapters. There are also twelve pages of plates-photographs, mostly, of people and apparatus, and generally woll reproduced. But only the last two chapters, which deal briefly with the Cavendish of to-day, are free from grave error: elsewhere history is misunderstood, geography is at fault and "the fundamental sciontific ideas and discoveries" are consistently made to appear trivial and irrelevant. It is a sorry story, signifying little or nothing on the intellectual level.

Let tho author spoak for himself: "This appointment [1871] showed great foresight, for Maxwell's most important work was still to come..." (p. 15); "His name was John Williarn Strutt Rayleigh . . . [in 1871] he married the sister of Arthur Baldwin, later the Earl of Baldwin, the statesman" (p. 22); "Professor Aston" (p. 27); "Sir James Clerk Maxwell" (p. 28); "Ernest Rutherford repeated Röntgon's experiments" (p. 31); "Henri Becquerel . . experimented with X-ray tubes. . . . But his assistant, Polish-born Marie Sklodowska, was not satisfied with the Professor's explanation ..." (p. 35); "It also meant that he could ask his fiancée to come to Montreal to marry him, which she gladly did" (p. 39) (Ruthorford, in fact, went home to New Zealand to be married,); "He talked with Niels Bohr, and some time later "tha penny dropped' " (p. 44) (this purports to be the inner story of the discovery of tho nucleus in 1911); "Soddy . . . was then 